\title{
Isolation and characterization of a new single-stranded DNA virus infecting the cosmopolitan marine diatom Chaetoceros debilis
}

\author{
Yuji Tomaru ${ }^{1, *}$, Yoko Shirai ${ }^{1}$, Hidekazu Suzuki ${ }^{2}$, Tamotsu Nagumo ${ }^{3}$, \\ Keizo Nagasaki ${ }^{1}$
}

\begin{abstract}
${ }^{1}$ Harmful Algal Bloom Division, National Research Institute of Fisheries and Environment of Inland Sea (FEIS), Fisheries Research Agency (FRA), 2-17-5 Maruishi, Hatsukaichi, Hiroshima 739-0452, Japan

${ }^{2}$ Department of Ocean Sciences, Tokyo University of Marine Science and Technology, 4-5-7 Konan, Minato-ku, Tokyo 108-8477, Japan

${ }^{3}$ Department of Biology, Nippon Dental University, 1-9-20 Fujimi, Chyoda-ku, Tokyo 102-8159, Japan
\end{abstract}

\begin{abstract}
The genus Chaetoceros (Bacillariophyceae) is the dominant diatom in the world's oceans. Various physical, chemical and biological factors affect depletion of diatom populations, for which the importance of viruses as a potential mortality source has only recently been found. We isolated and characterized a new Chaetoceros-infecting virus causing the lysis of the cosmopolitan species C. debilis Cleve. The virus infectious for C. debilis was isolated from both water and sediment samples collected in western Japan. We show the physiologic, morphologic and genomic characteristics of one virus clone among many isolates. We first described the C. debilis DNA virus (CdebDNAV), a $30 \mathrm{~nm}$ icosahedral virus accumulating in the cytoplasm of $C$. debilis. Host specificity of CdebDNAV is strain-specific and its infectivity is stably maintained through a wide temperature range (between 20 and $-196^{\circ} \mathrm{C}$ ). The latent period and the burst size were estimated to be 12 to $24 \mathrm{~h}$ and 55 infectious units per host cell, respectively. CdebDNAV harbors a single-stranded DNA (ssDNA) genome whose structure is unknown. Sequence comparisons showed that the partial sequence of CdebDNAV is highly similar $\left(E\right.$ value $\left.=10^{-56}\right)$ to the putative replicase gene of the $C$. salsugineum nuclear inclusion virus (CsNIV) that harbors a covalently closed circular, partially doublestranded ssDNA genome. This discovery of CdebDNAV may aid in further understanding the ecological dynamics of C. debilis population blooms in nature.
\end{abstract}

KEY WORDS: Diatom · Virus $\cdot$ Chaetoceros $\cdot$ DNA · Viral ecology

\section{INTRODUCTION}

Diatoms (Bacillariophyceae) account for a large part of marine primary production: up to $35 \%$ in oligotrophic oceans and $75 \%$ in nutrient-rich systems (Nelson et al. 1995). They play an important role in various marine systems as a food resource for zooplankton and animal larvae and are the primary oxygen producer for the atmosphere (Werner 1977). Among marine planktonic diatoms, Chaetoceros is the largest and most species-rich genus; more than 400 species have been described in this genus (Rines \& Hargraves 1988). Most are consid- ered to play an important role as primary photosynthetic producers in various marine environments, especially during their bloom periods (Rines \& Hargraves 1988). Some Chaetoceros species are harmful to aquaculture industries, e.g. mortalities in caged salmon due to C. concavicornis and C. convolutus blooms (Albright et al. 1993), and blooms of $C$. socialis often cause short-term depletion of nutrients that damage seaweed laver Porphyra yezoensis culture due to discoloration of thalli (S. Oda unpubl. data). Therefore, the dynamics of diatom blooms including Chaetoceros are important in marine biology, geochemistry, oceanography and the fisheries. 
Phytoplankton population dynamics are the result of imbalances between reproduction and losses. Losses include grazing, sinking and natural mortality. Since the early 1990s, the importance of viruses infectious to microalgae have been recognized as one of the principal causes of phytoplankton mortality. The direct evidence for the existence of diatom viruses were first reported in 2004 with the isolation of the diatominfecting Rhizosolenia setigera RNA virus (RsRNAV). This is a small (32 nm) icosahedral virus with singlestranded RNA (ssRNA) genome 8877 nt long excluding a poly-A tail (Nagasaki et al. 2004, Shirai et al. 2006). Thereafter, 2 Chaetoceros-infecting viruses were isolated and characterized: C. salsugineum nuclear inclusion virus (CsNIV), a small (38 nm) icosahedral virus harboring a covalently closed circular ssDNA (6000 nt) and a segment of linear ssDNA (997 nt) (Nagasaki et al. 2005, H. Mizumoto unpubl. data), and Chaetoceros nuclear inclusion virus (CspNIV) infectious to Chaetoceros cf. gracilis (Bettarel et al. 2005). These diatominfecting viruses were isolated from both waters and sediments during and after diatom blooms, and each virus is specifically infectious to its host diatom. Hence, viral infection may be an important factor in regulating the population dynamics of the corresponding diatom species.

In the present study we report the isolation of a new ssDNA virus (CdebDNAV) infecting Chaetoceros debilis Cleve, one of the dominant phytoplankton spe- cies in marine environments, occasionally accounting for $>80 \%$ of a diatom community (Ishikawa \& Furuya 2004, Lopez-Cortes et al. 2006). We also show the virus' physiologic, morphologic and genomic features.

\section{MATERIALS AND METHODS}

Algal cultures and growth conditions. The algal strains used in the present study are shown in Table 1 and Fig. 1 and include Chaetoceros debilis 020810A04 maintained at the National Research Institute of Fisheries and Environment of the Inland Sea (Japan). Algal cultures were grown in modified SWM3 medium enriched with $2 \mathrm{nM} \mathrm{Na}_{2} \mathrm{SeO}_{3}$ (Itoh \& Imai 1987) under a $12: 12 \mathrm{~h}$ light:dark cycle of ca. 110 to $150 \mu \mathrm{mol}$ of photons $\mathrm{m}^{-2} \mathrm{~s}^{-1}$ using cool white fluorescent illumination at $15^{\circ} \mathrm{C}$, except for the algal strains maintained at $20^{\circ} \mathrm{C}$ as shown in Table 1.

Isolation of virus. Water samples (depths: 0 [sea surface] and $1 \mathrm{~m}$ above bottom) (Sampling Stns 1, 2, 3, 4 and 5) and sediment samples (0 to $3 \mathrm{~cm}$ depth) (Sampling Stns 1 and 5) were obtained from the mouth of the Shiotsuka River in Ariake Sound, Japan, from 12 March 2003 to 7 December 2005. Ariake Sound is a semi-enclosed, shallow and productive estuarine system in western Japan with an area of $1700 \mathrm{~km}^{2}$ and an average water depth of $20 \mathrm{~m}$ (e.g. Yokoyama et al. 2005, Nakamura \& Hirata 2006). Collected samples

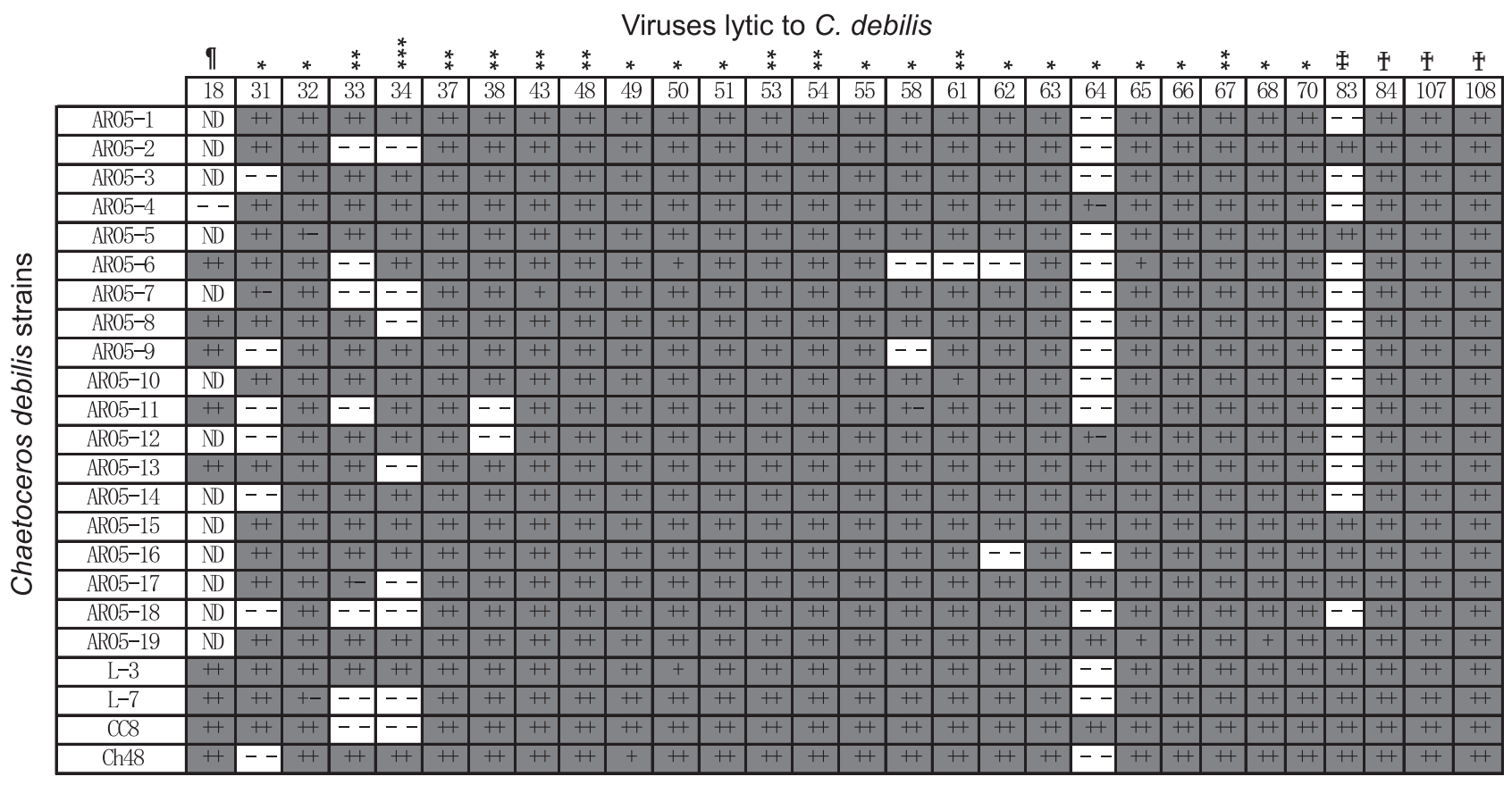

Fig. 1. Viral susceptibility of 23 Chaetoceros debilis strains to 29 virus clones isolated from Ariake Sound, Japan. Shaded and open columns indicate susceptibility (with apparent cell lysis at 1 time ' +- ' and 2 times ' ++ ' in duplicate tests) and resistance (with cell growth equal to the controls at 2 times ' $--^{\prime}$ ) of the host strains to each virus isolate, respectively. Il, *, **, ***, $\mp$ and $\$$ : virus was isolated with C. debilis strain 020810A04, CC8, Ch48, 020810A01, L-7 and D-9, respectively. ND = no data 
Table 1. Infection specificities of Chaetoceros debilis DNA virus (CdebDNAV18) against 45 strains of marine phytoplankton. -: not lysed + +: lysed

\begin{tabular}{|c|c|c|c|c|}
\hline Family & Species & Strain code & $\begin{array}{c}\text { Temperature } \\
\left({ }^{\circ} \mathrm{C}\right)\end{array}$ & $\begin{array}{l}\text { Strains lysed by } \\
\text { CdebDNAV18 }\end{array}$ \\
\hline \multirow{29}{*}{ Bacillariophyceae } & Asterionella glacialis & $\mathrm{E}-10$ & 15 & - \\
\hline & Chaetoceros debilis & 020810A01 & 15 & - \\
\hline & Chaetoceros debilis & Ch48 & 15 & + \\
\hline & Chaetoceros debilis & L-1 & 15 & + \\
\hline & Chaetoceros debilis & L-6 & 15 & + \\
\hline & Chaetoceros tenuissimus & 020710MA01 & 15 & - \\
\hline & Chaetoceros tenuissimus & 020711IT01 & 15 & - \\
\hline & Chaetoceros salsugineum & Ch42 & 15 & - \\
\hline & Chaetoceros socialis f. radians & $\mathrm{L}-4$ & 15 & - \\
\hline & Chaetoceros sp. & 020710IT04 & 15 & - \\
\hline & Chaetoceros sp. & 020710OS02 & 15 & - \\
\hline & Chaetoceros sp. & a6 & 15 & - \\
\hline & Chaetoceros sp. & $\mathrm{C}-11$ & 15 & - \\
\hline & Chaetoceros sp. & $\mathrm{C}-12$ & 15 & - \\
\hline & Chaetoceros sp. & CDeb200111A & 15 & - \\
\hline & Chaetoceros sp. & CDid200111A & 15 & - \\
\hline & Chaetoceros sp. & $\mathrm{CM}-4$ & 15 & - \\
\hline & Chaetoceros sp. & CS200111A & 15 & - \\
\hline & Chaetoceros sp. & K-3 & 15 & - \\
\hline & Chaetoceros sp. & L-2 & 15 & - \\
\hline & Chaetoceros sp. & L-8 & 15 & - \\
\hline & Chaetoceros sp. & L-9 & 15 & - \\
\hline & Coscinodiscus sp. & 021121AR02 & 15 & - \\
\hline & Ditylum brightwellii & Dity & 15 & - \\
\hline & Eucampia zodiacus & $\mathrm{B}$ & 15 & - \\
\hline & Rhizosolenia setigera & $\mathrm{S} 2$ & 15 & - \\
\hline & Stephanopyxis sp. & SP199704 & 15 & - \\
\hline & Thalassionema sp. & $\mathrm{I}-2$ & 15 & - \\
\hline & Thalassiosira sp. & $\mathrm{C}-7$ & 15 & - \\
\hline Eustigmatophyceae & Nannochloropsis sp. & SFBB & 20 & - \\
\hline Chlorophyceae & Oltmannsiellopsis viridis & Olt1-3 & 20 & - \\
\hline \multirow[t]{8}{*}{ Dinophyceae } & Akashiwo sanguineum & G-8 & 15 & - \\
\hline & Alexandrium catenella & ACNG & 20 & - \\
\hline & Gymnodinium catenatum & GC27-1 & 20 & - \\
\hline & Heterocapsa circularisquama & HU9433-P & 20 & - \\
\hline & Heterocapsa triquetra & $\mathrm{Ht}$ & 20 & - \\
\hline & Karenia mikimotoi & G303-ax2 & 20 & - \\
\hline & Prorocentrum micans & 8304 & 20 & - \\
\hline & Scrippsiella sp. & SCKR & 20 & - \\
\hline \multirow{6}{*}{ Raphidophyceae } & Chattonella verrculosa & $\mathrm{M}$ & 15 & - \\
\hline & Chattonella antiqua & CaAR & 20 & - \\
\hline & Chattonella marina & CmKG-1 & 20 & - \\
\hline & Chattonella ovata & $\mathrm{CoV}$ & 20 & - \\
\hline & Fibrocapsa japonica & FE985 & 20 & - \\
\hline & Heterosigma akashiwo & H93616 & 20 & - \\
\hline
\end{tabular}

were sent to the laboratory without fixation within $24 \mathrm{~h}$ of sampling and stored at $4^{\circ} \mathrm{C}$. The water samples were filtered through $0.2 \mu \mathrm{m}$ Dismic-25 cs filters (Advantec) to remove eukaryotic microorganisms and most bacteria. Of each sediment sample, $12 \mathrm{~g}$ was shaken with $12 \mathrm{ml}$ of $\mathrm{Na}_{2} \mathrm{SeO}_{3}$-enriched SWM3 (400 rpm, $23^{\circ} \mathrm{C}$, for $30 \mathrm{~min}$ ) and centrifuged at $860 \times g$ at $4^{\circ} \mathrm{C}$ for $10 \mathrm{~min}$. The supernatants were sequentially passed through Whatman GF/F and $0.2 \mu \mathrm{m}$ Dismic-25 cs filters. Aliquots $(0.2 \mathrm{ml})$ of the filtrates obtained from water and sediment samples were inoculated into exponen- tially growing Chaetoceros debilis cultures $(0.8 \mathrm{ml})$ followed by incubation at $15^{\circ} \mathrm{C}$ using the lighting conditions above. Algal cultures inoculated with SWM3 served as controls. A C. debilis 020810A04 culture inoculated with the filtrate of surface water from Stn 3 on 12 March 2003 showed inhibition of algal growth (Fig. 2A). Since the pathogen for C. debilis 020810A04 was also infectious to $C$. debilis Ch48 (Fig. 2B), we maintained the virus using the latter host strain because the former host culture (020810A04) was lost during the pathogen cloning procedure. We cloned the 


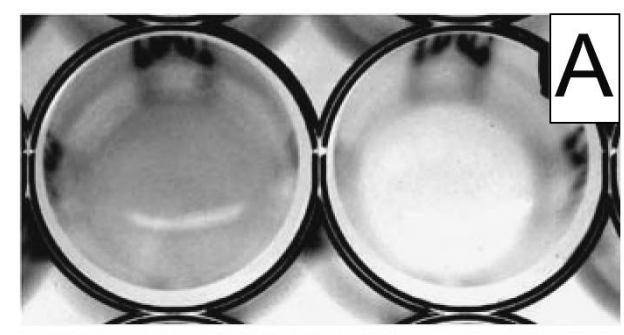

Fig. 2. Chaetoceros debilis Ch48. (A) C. debilis cultures with (right) or without (left) inoculation of CdebDNAV; optical microgragphs of (B) intact cells and (C) CdebDNAV-infected C. debilis cells. Scale bars $=10 \mu \mathrm{m}$
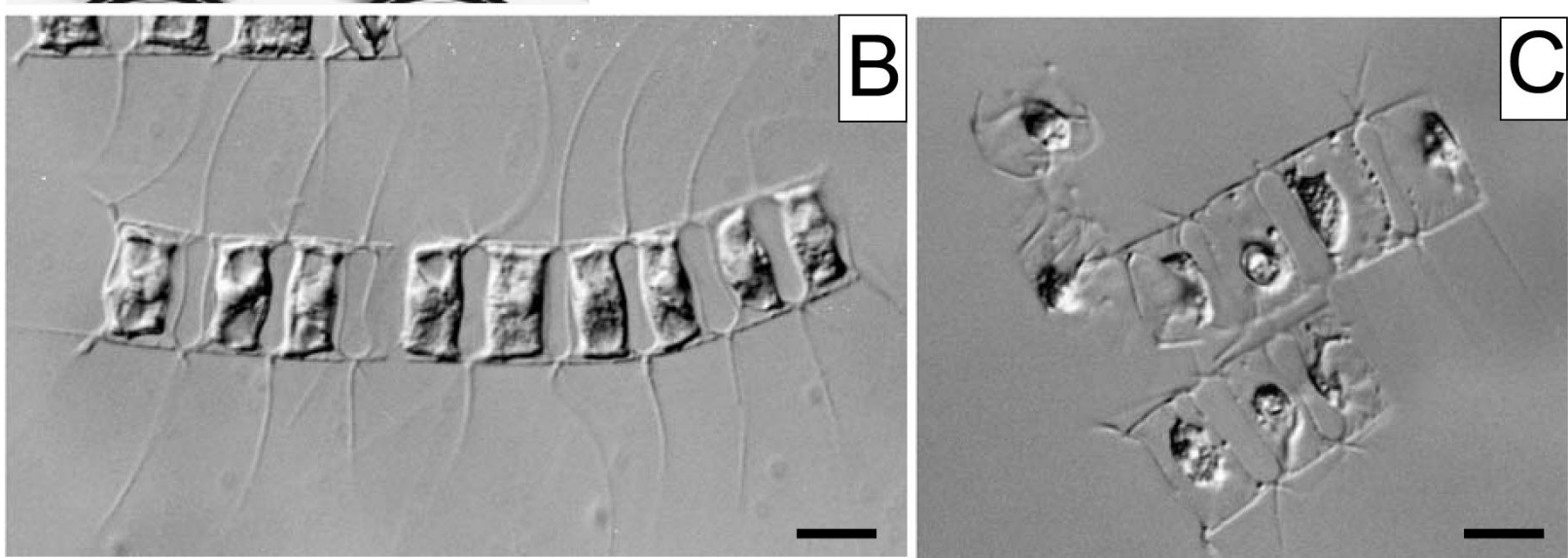

pathogen through 2 extinction dilution cycles (Suttle 1993, Tomaru et al. 2004a) using lysed cultures of $C$. debilis Ch48. The lysate in the highest dilution well of the second assay was made free of bacterial contamination using filtration through a $0.1 \mu \mathrm{m}$ polycarbonate membrane filter (Nuclepore) and was transferred to another exponentially growing host culture. The resultant lysate was regarded as a clonal virus suspension. The virus characterization data presented in the present study were from a virus lytic to C. debilis Ch48 isolated from Ariake Sound surface water on 12 March 2003 and later designated CdebDNAV18.

From Ariake Sound water and sediment samples, taken from April 2003 to December 2005, we isolated clones of viruses that also lysed cultures of Chaetoceros debilis Ch48, CC8, 020810A01, 020810A04, D-9, L-1, L-3, L-6 and L-7. These viral isolates were stored at $-20^{\circ} \mathrm{C}$ before analysis. We used 29 of the 118 isolated virus clones including CdebDNAV18 for intraspecies host specificity tests.

Host range. The intra-species host specificity of 29 virus clones including CdebDNAV18 was tested by adding $5 \%(\mathrm{v} / \mathrm{v})$ aliquots of fresh lysate passed through $0.2 \mu \mathrm{m}$ filters to duplicate cultures of 23 exponentially growing Chaetoceros debilis clonal strains shown in Fig. 1. Nineteen clones of the 23 C. debilis strains used for the intra-species host specificity test were isolated from the water sample collected on 17 December 2005 in Ariake Sound during a C. debilis bloom. They were cultured under the conditions given above at $15^{\circ} \mathrm{C}$. Inter-species host specificity for virus
CdebDNAV18 was tested by adding $5 \%$ (v/v) aliquots of fresh lysate passed through $0.2 \mu \mathrm{m}$ filters into duplicate cultures of exponentially growing clonal algal strains that belong to the families Bacillariophyceae, Chlorophyceae, Dinophyceae, Eustigmatophyceae and Raphidophyceae shown in Table 1 . They were cultured under the conditions given above at the temperatures shown in Table 1. The growth and evidence of lysis in each algal culture in both experiments were monitored by optical microscopy and compared to control cultures inoculated with SWM3. Cultures apparently not lysed at $14 \mathrm{~d}$ post-inoculation (pi) were considered to be unsuitable hosts for the viral pathogen.

Transmission electron microscope (TEM). An exponentially growing culture of Chaetoceros debilis Ch48 was inoculated with CdebDNAV18 at a multiplicity of infection of 2.4. As a control a C. debilis Ch48 culture was inoculated with an autoclaved viral suspension. An aliquot of cell suspension was sampled at $36 \mathrm{~h}$ pi. $C$. debilis Ch48 cells were harvested by centrifugation at $860 \times g$ at $4^{\circ} \mathrm{C}$ for $10 \mathrm{~min}$ and fixed with $1 \%$ glutaraldehyde in SWM3 for $4 \mathrm{~h}$ at $4^{\circ} \mathrm{C}$. The cell pellets were post-fixed for $3 \mathrm{~h}$ in $2 \%$ osmic acid in $0.1 \mathrm{M}$ phosphate buffer ( $\mathrm{pH} 7.2$ to 7.4 ), dehydrated in a graded ethanol series (50 to $100 \%$ ) and embedded in Quetol 653 resin (Nisshin EM). Ultra-thin sections were stained with $4 \%$ uranyl acetate and $3 \%$ lead citrate and observed at $80 \mathrm{kV}$ using a JEOL JEM-1010 TEM. CdebDNAV18 particles negatively stained with uranyl acetate were also observed using TEM. The virus suspension was mounted on a grid (no. 780111630; JEOL Datum) for 
$30 \mathrm{~s}$, and excess water was removed using filter paper (No. 1; TOYO). Then $4 \%$ uranyl acetate was applied for $10 \mathrm{~s}$ and excess dye was removed using a filter paper. After the grid was dried in a desiccator for $2 \mathrm{~h}$, negatively stained CdebDNAV18 particles were observed using TEM at an acceleration voltage of $80 \mathrm{kV}$. Particle diameters were estimated using the negatively stained images.

Thermal stability. An exponentially growing culture of Chaetoceros debilis Ch48 was inoculated with virus CdebDNAV18 and incubated for $4 \mathrm{~d}$. The lysate was passed through a $0.2 \mu \mathrm{m}$ filter to remove cellular debris. The titer of the resultant fresh lysate was then estimated using the extinction dilution method, and aliquots of the lysate were stored at 20, 10, 4, -20, -80 and $-196^{\circ} \mathrm{C}$ (in liquid nitrogen) in the dark without the addition of cryoprotectants. Further titration was performed at $28 \mathrm{~d}$ of storage to determine the stability of the virus at each temperature.

CdebDNAV nucleic acids. A $450 \mathrm{ml}$ exponentially growing Chaetoceros debilis Ch48 culture was inoculated with $15 \mathrm{ml}$ of virus CdebDNAV18 suspension and lysed. The lysate was centrifuged at $4500 \times g$ at $4^{\circ} \mathrm{C}$ for $10 \mathrm{~min}$, and the supernatant was sequentially passed through 0.8 and $0.2 \mu \mathrm{m}$ polycarbonate membrane filters to remove cellular debris. Polyethylene glycol 6000 (Wako Pure Chemical Industries) was added to the filtrate to a final concentration of $10 \%(\mathrm{w} / \mathrm{v})$, and the suspension was stored at $4^{\circ} \mathrm{C}$ in the dark overnight. After centrifugation at $57000 \times g$ at $4^{\circ} \mathrm{C}$ for $1.5 \mathrm{~h}$, the pellet was washed with $10 \mathrm{mM}$ phosphate buffer $(\mathrm{pH}$ 7.2) and centrifuged again at $217000 \times g$ at $4^{\circ} \mathrm{C}$ for $4 \mathrm{~h}$ to collect the virus particles. They were re-suspended in $500 \mu \mathrm{l}$ of ultra-pure water. The viral suspension was treated with Proteinase K (1 mg ml-1, Wako Pure Chemical Industries) and sarcosyl (1\%; International Technologies) at $55^{\circ} \mathrm{C}$ for $1.5 \mathrm{~h}$. Nucleic acids were extracted from the pellet using the phenol-chloroform method (Yamada et al. 1991).

The nucleic acid samples were digested with RNase A (Nippon Gene) at $0.05 \mu \mu^{-1}$; DNase I (Promega) at

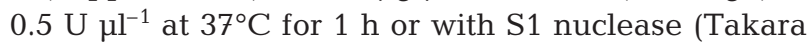
Bio) at $0.7 \mathrm{U} \mathrm{\mu l}^{-1}$ at $23^{\circ} \mathrm{C}$ for $15 \mathrm{~min}$. The nucleic acid samples were heat-treated at $100^{\circ} \mathrm{C}$ for 5 min followed by cooling on ice. Nucleic acid extracts held on ice without any treatment served as controls. The nucleic acid samples thus prepared were electrophoresed in agarose gels (1\%; SeaKem Gold Agarose; BMA) at $50 \mathrm{~V}$ for $1 \mathrm{~h}$. Nucleic acids were visualized using SYBR-Gold staining (Molecular Probes).

Partial genome sequence. The nucleic acids purified using the phenol-chloroform extraction method (Yamada et al. 1991) were further treated using a modified CTAB extraction method described by Lian et al. (2001), and the nucleic acids were used for the follow- ing sequence analysis. Complementary DNA was synthesized using a modified method described by Gubler \& Hoffman (1983). Briefly, viral nucleic acid primed with random hexa-nucleotides was used as the template for T4 DNA polymerase. The synthesized dsDNA was digested with EcoRV and ligated into the pBluescript II SK(+) vector digested with EcoRV using a Ligation High Kit (Toyobo) according to the manufacturer's recommendations. After the resultant plasmids were transformed into Escherichia coli DH5 $\alpha$-competent cells (Toyobo), sequencing was conducted using the dideoxy method with an ABI PRISM 3100 Genetic Analyzer (Applied Biosystems).

CdebDNAV proteins. The CdebDNAV18 suspension was mixed with 4 volumes of sample buffer $(62.5 \mathrm{mM}$ Tris- $\mathrm{HCl}, 5 \%$ 2-mercaptoethanol, 2\% sodium dodecyl sulfate [SDS], 20\% glycerol, $0.005 \%$ bromophenol blue) and boiled for $5 \mathrm{~min}$. The proteins were then separated using SDS-polyacrylamide gel electrophoresis $(80 \times 40 \times 1 \mathrm{~mm}, 12.5 \%$ polyacrylamide, $150 \mathrm{~V})$ using the XV Pantera System (DRC). Proteins were visualized using Coomassie brilliant blue staining. Protein molecular mass standards (DRC) ranging from 6.5 to $200 \mathrm{kDa}$ were used for size calibration.

One-step growth experiment. An exponentially growing culture of Chaetoceros debilis Ch48 (40 ml) was inoculated with CdebDNAV18 at a multiplicity of infection of 8.3. A C. debilis Ch48 culture inoculated with an autoclaved viral suspension served as a control. An aliquot of the cell suspension was sampled from each culture at $0,12,24,36,48,60,72,96$ and $114 \mathrm{~h} \mathrm{pi}$, and the number of host cells and lytic agents were estimated. The number of lytic agents was determined using the extinction dilution method (Suttle 1993, Tomaru et al. 2004a). The experiments were conducted in duplicate.

\section{RESULTS AND DISCUSSION}

\section{Isolation of the viral pathogen}

Most of the viruses infectious to Chaetoceros debilis were isolated during lower temperature seasons, late autumn to late spring, from both water and sediment samples. All isolates retained their algicidal activity after filtration through a $0.1 \mu \mathrm{m}$ filter. The algicidal activities were serially transferable to exponentially growing $C$. debilis cultures, which were same strains used for the virus isolations (data not shown). Cultures and cells of $C$. debilis Ch48 lysed by the virus became pale in color, presumably due to the loss or degradation of photosynthetic pigments (Fig. 2). A cross-reactivity test between 29 virus clones and 23 C. debilis strains showed that the intra-species host ranges of these 
viruses were diverse (Fig. 1). Since all of the viruses were not characterized in the present study, it is unknown whether the host range diversity of the viruses reflects the existence of multiple virus species or whether a single virus species has diverse intra-species host specificity. Among the virus clones isolated, the characteristics of CdebDNAV18 were further examined in the present study.

\section{Host range}

The host range of CdebDNAV18 was tested using 46 phytoplankton strains including 26 diatom strains; 4 of them were Chaetoceros debilis strains isolated from the coastal waters of western Japan. CdebDNAV18 caused lysis in only $C$. debilis strains and not any other microalgal species tested (Table 1). This shows that the virus has a high infection specificity. However, $C$. debilis strains 020810A01 and AR05-4 did not lyse after inoculation with CdebDNAV18 (Table 1, Fig. 1), suggesting that this virus is strain-specific as observed in other algal viruses, e.g. HcRNAV (Tomaru et al. 2004a) and RsRNAV (Nagasaki et al. 2004).

\section{Morphological features}

Thin sections of healthy Chaetoceros debilis Ch48 cells showed the cytoplasmic organization and frustules were typical of these diatoms (Fig. 3A). In contrast, electron micrographs of thin-sectioned $C$. debilis $\mathrm{Ch} 48$ cells at $36 \mathrm{~h}$ pi with virus showed the presence of small virus-like particles (VLPs) randomly assembled in the host cytoplasm (Fig. 3B,C). Occasionally, VLP accumulations were observed inside the nuclear envelope (Fig. 3D,E). With CsNIV (Nagasaki et al. 2005) and CspNIV (Bettarel et al. 2005), accumulation of VLPs were observed in the nucleus. CdebDNAV18 particles may also possibly accumulate in the nucleus of C. debilis cells. Formation of crystalline arrays of VLPs was not observed. No VLPs were found in healthy control cultures (Fig. 3A). Further, VLPs were observed in culture lysates using negative staining. They were icosahedral in shape, $30 \pm 2 \mathrm{~nm}(\mathrm{n}=36)$, and lacked a tail or an outer membrane (Fig. 3F). Since (1) the algicidal pathogen was transferable to a fresh algal culture, (2) VLPs were observed in the lysed culture and (3) the VLPs were not found in healthy cultures, Koch's postulates were fulfilled. We concluded that the VLP observed within the infected cells and in the algal lysates was a previously undescribed virus pathogenic in C. debilis.

For RsRNAV, the frustule pores of its host Rhizosolenia setigera are larger than RsRNAV particles, so it is considered to be a possible route of viral infection (Nagasaki et al. 2004); in contrast, the frustule pores of Chaetoceros debilis are not large enough for the virus particles to pass through (data not shown). Future study is necessary to determine the adsorption and infection route for this virus.

\section{Thermal stability}

CdebDNAV18 suspensions containing $7.7 \times 10^{5}$ and $1.4 \times 10^{6}$ infectious units $\mathrm{ml}^{-1}$ were stored at $20,10,4,-20$ and $-196^{\circ} \mathrm{C}$ and at $-80^{\circ} \mathrm{C}$, respectively. The infectious titers of the virus suspension after $28 \mathrm{~d}$ of storage at 20 , $10,4,-20,-80$ and $-196^{\circ} \mathrm{C}$ in the dark decreased or increased to $3.9 \times 10^{5}, 7.0 \times 10^{5}, 3.9 \times 10^{5}, 1.1 \times 10^{5}, 1.6 \times 10^{6}$ and $7.0 \times 10^{6}$ infectious units $\mathrm{ml}^{-1}$, respectively. Thus, there was no significant loss of the infectious titers using any of the conditions tested. The infectivity of the pathogenic viruses isolated from both waters and sediments during the present study period was not lost after storage at $-20^{\circ} \mathrm{C}$ (data not shown). The virus has a high thermal stability and the sediment may be a stable reservoir for it. This is also observed in other algal viruses, e.g. HcRNAV and the viruses infectious to Heterosigma akashiwo isolated from near British Columbia (Lawrence et al. 2002, Nagasaki et al. 2004, Tomaru et al. 2007).

\section{Genome and proteins}

Agarose gel electrophoresis showed that the major nucleic acids extracted from CdebDNAV18 were at ca. 7, 5, 1.4 and $0.8 \mathrm{~kb}$ having a band with the highest mobility that was much stronger than the other 3 bands (Fig. 4). Using denaturing gel electrophoresis a similar band pattern was observed (data not shown). The major bands were not sensitive to RNase A, but DNase I and S1 nuclease completely digested the extracted nucleic acids (Fig. 4). These data suggest that the genome is ssDNA. Therefore, this new virus was designated as Chaetoceros debilis DNA virus (CdebDNAV), named after its host species and genome type.

The nucleic acid band positions were not significantly different after heat treatment at $100^{\circ} \mathrm{C}$ for $5 \mathrm{~min}$, where the $7 \mathrm{~kb}$ band was slightly weaker after heat treatment (Fig. 4). This suggests that the first band was sensitive to heat treatment. Similarly we observed this in a previous study using the CsNIV genome. The CsNIV genome consists of a single molecule of covalently closed circular ssDNA (6000 nt), as well as a segment of linear ssDNA (997 nt) (Nagasaki et al. 2005, H. Mizumoto pers. comm.). The intact CsNIV genome exhibits 3 major bands of nucleic acids at ca. 8, 6 and $1 \mathrm{~kb}$, and after heat treatment at $100^{\circ} \mathrm{C}$ for $10 \mathrm{~min}$ the 

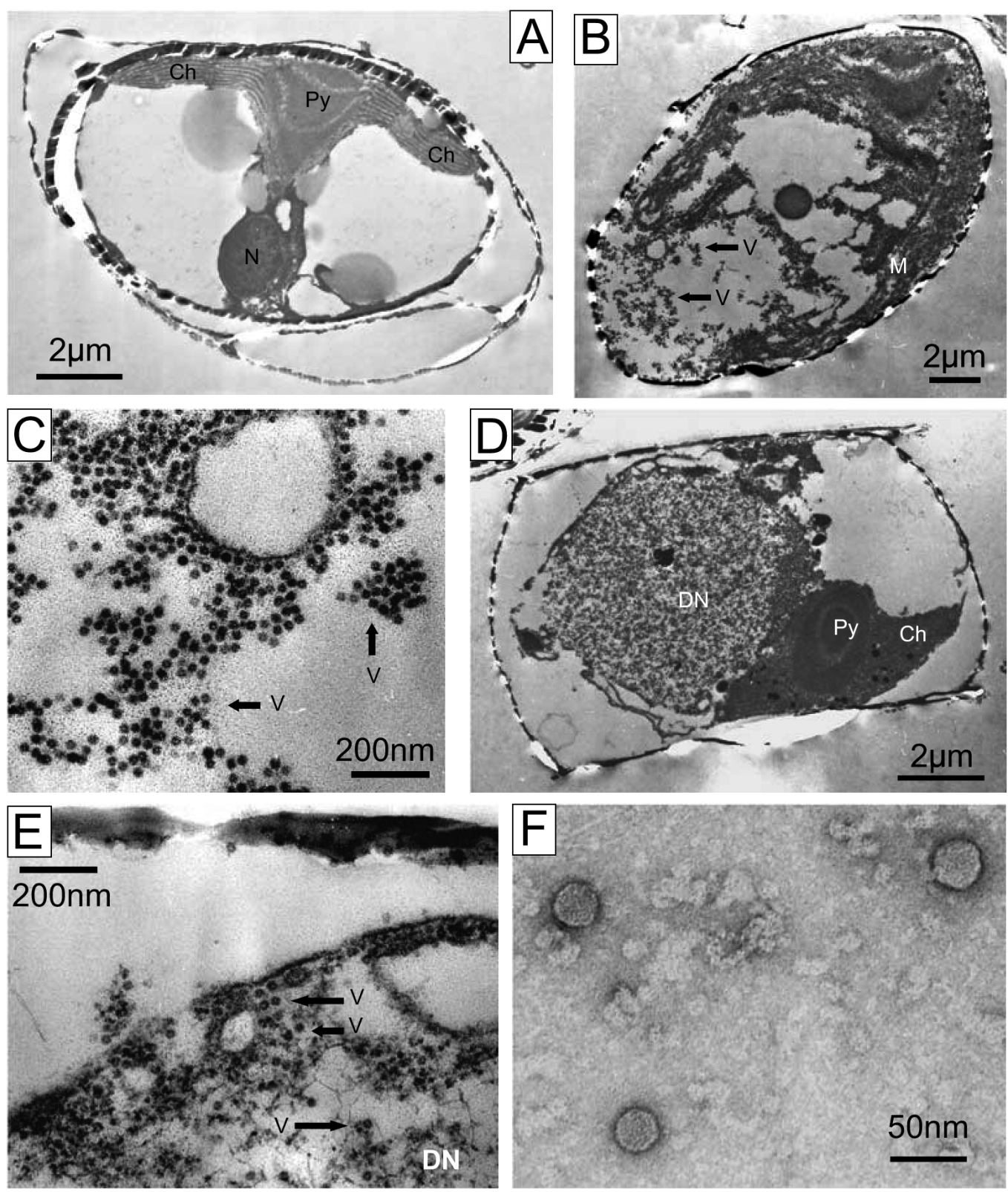

Fig. 3. Transmission electron micrographs (TEM) of ultra-thin sections of Chaetoceros debilis Ch48 and negatively stained CdebDNAV particles. (A) Healthy cell. (B-E) Cells infected with CdebDNAV18 at 36 h post-inoculation. (B) Accumulation of virus-like particles (VLPs) in the cytoplasm. (C) Higher magnification of the VLPs in the cytoplasm. (D) VLPs located within the nucleus. (E) Higher magnification of the VLPs. (F) Negatively stained CdebDNAV18 particles in the culture lysate. Ch: chloroplast; DN: degraded nucleus; M: mitochondrion; N: nucleus; Py: pyrenoid; V: VLP

first band weakened while the second strengthened (Nagasaki et al. 2005). This may be due to the first and second bands being 'covalently closed circular DNA with a lower mobility' and a 'linear form of the same molecule with higher mobility', respectively. Therefore, the first band from the CdebDNAV18 genome may be a covalently closed circular ssDNA. Further study is needed to show the genome structure of this virus.
The CdebDNAV18 genome was partially sequenced (ca. $1200 \mathrm{nt}$ ) showing an open reading frame (744 nt). The deduced amino acid sequence had high similarity $\left(\mathrm{E}\right.$ value $\left.=10^{-56}\right)$ to a putative replicase of CsNIV (Fig. 5). This enzyme similarity suggests that this virus may be from the ssDNA virus group infecting Chaetoceros species; also the possible structure of the CdebDNAV18 genome could be a covalently closed circular ssDNA. Further characterization of the viral genome is 


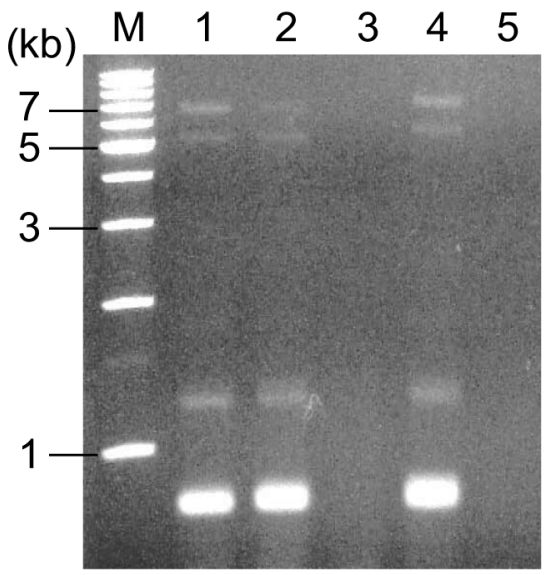

Fig. 4. Nucleic acids of CdebDNAV18 without treatment (lane 1), with treatment at $100^{\circ} \mathrm{C}$ for 5 min (lane 2), treatment with DNase I (lane 3), RNase A (lane 4) and S1 nuclease (lane 5) electrophoresed in an agarose gel. DNA molecular weight markers are shown in lane $\mathrm{M}$

necessary to determine the detailed classification and nomenclature of CdebDNAV18.

The size and numbers of structural proteins composing the virus particles were determined using SDS-polyacrylamide gel electrophoresis. CdebDNAV18 contains 2 major polypeptides at 41.0 and $37.5 \mathrm{kDa}$ (Fig. 6). The number of major proteins of CdebDNAV18 was the same as that of CsNIV, 46.0 and $43.5 \mathrm{kDa}$ (Nagasaki et al. 2005).

\section{Replication}

Using a one-step growth experiment, a significant increase in virus abundance was noticed from 12 to $24 \mathrm{~h}$ pi (Fig. 7); thus, the latent period of CdebDNAV18

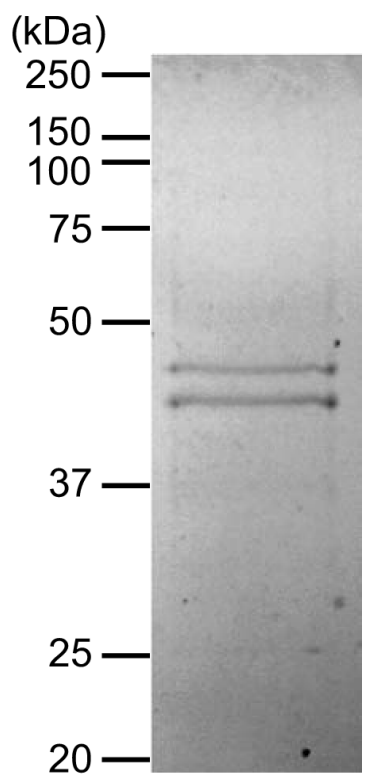

Fig. 6. Major structural proteins of CdebDNAV18

was estimated to be $<24 \mathrm{~h}$. In contrast, the decrease in host cell number was obvious from 36 to $96 \mathrm{~h}$ pi (Fig. 7). If the multiplicity of infection (8.3) was high enough to expose all of the cells to viral attack (i.e. to make all the sensitive cells infected), we presume that the viral infection does not necessarily interrupt algal binary fission. This was observed with RsRNAV and CsNIV (Nagasaki et al. 2005), as we observed a slight increase in host cell numbers even after virus inoculation (Fig. 7). One possible explanation may be that virus sensitivity was highly diverse among cells in the host culture even though it was a clonal culture; i.e. some expressed sensitivity and some did not, and only a portion of host cells were immediately infected with

\begin{tabular}{|c|c|c|c|}
\hline CdebDNAV18 & 9 & WADI LHKDDESRALLASCGWAKGFHKER INKIELREIKGNT IMYGAGGTGKTTCVMAFNP & 68 \\
\hline & & $\mathrm{W} \quad \mathrm{I}+\mathrm{H}+\mathrm{D} \mathrm{S}+\mathrm{LL}+\mathrm{C} \mathrm{W}++\mathrm{H} \quad \mathrm{R}$ & \\
\hline CsNIV21 & 315 & WDQIVHESDHSKKLLCTCSWGQKYHAGRRASDPRRT I SNVI I LYGAGGTGKTTTAHDWDP & 374 \\
\hline CdebDNAV18 & 69 & $\begin{array}{l}\text { TD-KTAPRSVY I KNYGEGDFWGGGATAYKNEAKLLFEEFEGQITLSSLKMICDLGKSGPN } \\
++\mathrm{T} \quad \mathrm{Y}+\mathrm{N}+\mathrm{G} \text { FWG } \mathrm{G}+\mathrm{AY}++\mathrm{FEEF} \text { GQ S LK +CD+GKSGP }\end{array}$ & 127 \\
\hline CsNIV21 & 375 & REGETQKERYYRRNPDDGHFWGAGRSAYNGQRIVHFEEFTGQEAFSRLKEVCDIGKSGPT & 434 \\
\hline CdebDNAV18 & 128 & $\begin{array}{l}\text { INIKNGGAKLNHDEVFFCSNSHPAGWFRGVWKKDPKQWEPFRRRITKVLFFPEFRPDGSR } \\
\text { INIKN G +LNH+ V F SN HPAGWF +WK DPKQ+ PF RR+T+V F+P R DG+ }\end{array}$ & 187 \\
\hline CsNIV21 & 435 & INI KNSGGELNHETVIFTSNVHPAGWFHKLWKDDPKQFHPFWRRVTEVRFYPTHRADGAL & 494 \\
\hline CdebDNAV18 & 188 & $\begin{array}{l}\text { NEPDDEHNPYI IDQTEEWNTWKGEEGLVKAAEHAAIHWPLK } \\
\begin{array}{lllll}\mathrm{N} P D+\mathrm{H} & \mathrm{IDQT} & \mathrm{EW}+\mathrm{G}+\mathrm{KA} & \mathrm{HA} & + \text { WPLK }\end{array}\end{array}$ & \\
\hline CsNIV21 & 495 & NI PDQDHP PAF IDQTGEWREFGGD - - YQKALAHADTYWPLK & \\
\hline
\end{tabular}

Fig. 5. Comparison of the partial amino acid sequence of putative replication-associated proteins of Chaetoceros salsugineum nuclear inclusion virus (CsNIV21) (Nagasaki et al. 2005) and CdebDNAV18 (present study). Numbers correspond to the amino acid position. Letters: identical amino acid; +: functionally similar amino acid 


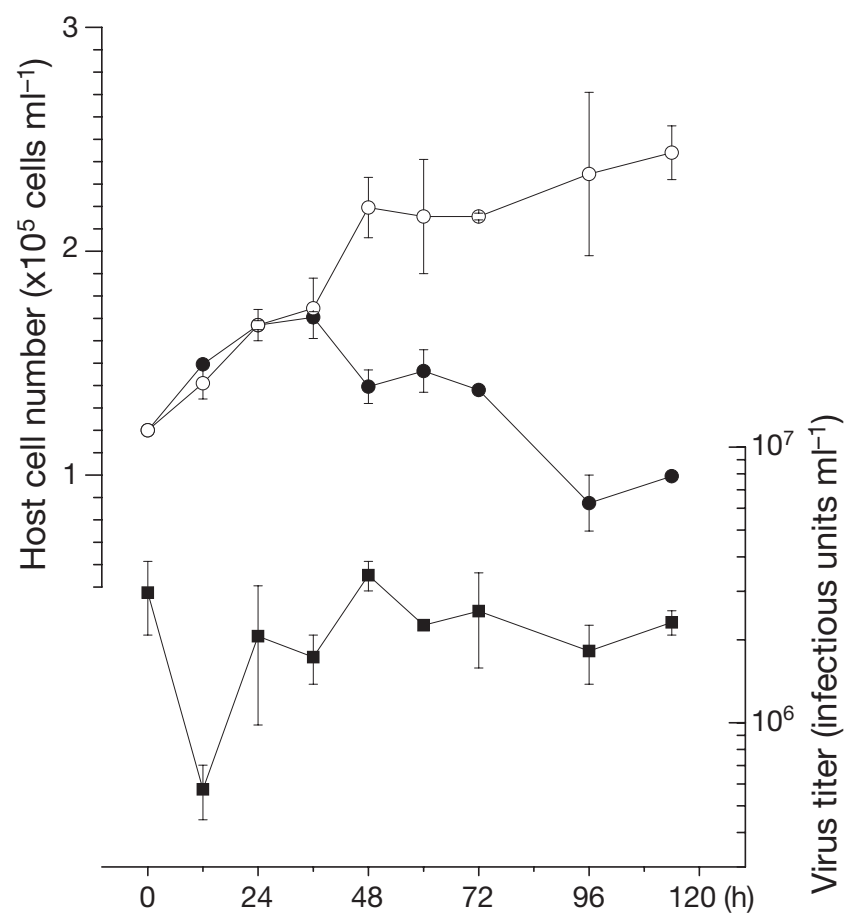

Fig. 7. Changes in cell numbers of Chaetoceros debilis Ch48 used for the 1-step growth experiments with $(\bullet)$ or without $(\mathrm{O})$ virus inoculation, and the virus titer (घ). Virus inoculation was performed at $0 \mathrm{~h}$ in an exponentially growing host culture using a multiplicity of infection of 8.3. Error bars indicate the difference between the host cell numbers and virus titers obtained in the duplicate test

CdebDNAV, lysed and produced daughter virus particles. Similar reproduction has been observed in other algal host-virus relationships (Thyrhaug et al. 2003).

It was therefore considered difficult to estimate burst size. The host:virus ratio at 36 to $48 \mathrm{~h}$ pi was used to calculate the burst size and was estimated to be 55 infectious units cell ${ }^{-1}$. By comparing this data and the particle numbers found in thin section views of the infected cells, this value may be underestimated. Similar underestimation was found with CsNIV (Nagasaki et al. 2005). Possible explanations for the small burst size may be aggregation of virus particles causing an underestimation of the most probable number, difficulties in distinguishing dead cells and living cells by optical microscopy or a dominance of defective particles lacking infectivity.

In growth experiments the cultures did not completely lyse even at $114 \mathrm{~h}$ pi. In the cross reactivity tests using the Chaetoceros debilis Ch48 culture inoculated with CdebDNAV18, we observed that most of the host cells degraded, but some surviving single rounded cells had red fluorescence with blue light excitation and were detected in the infected cultures at $10 \mathrm{~d}$ pi, indicating viability. The survivor $C$. debilis cells did not re-grow in the infected cultures (data not shown). Although we do not know the physiological condition of these survivor cells, they may be resting spores or resting cells (hereafter referred to as 'resting stages' for both types), which may be resistant to viral infection. This was seen for Heterocapsa circularisquama virus (HcV) (Tarutani et al. 2001). The temporary cystlike $H$. circularisquama cells, which are survivors after viral attacks, have growth potential in a virus-free culture. Tarutani et al. (2001) concluded that these temporary cyst-like cells may be resistant to viral attack. Similarly the resting stages of $C$. debilis may be able to escape viral attacks to sustain the population in nature. The relationship between virus infection and the resting stages of $C$. debilis may be key in determining the life cycle of $C$. debilis in natural environments.

\section{Ecological implication}

Because the intra-species host specificity is highly diverse among the virus clones tested, a natural Chaetoceros debilis population is considered to be composed of diverse host strains that have different virus sensitivity spectra. Previous studies with microalgal host-virus systems report similar data. Heterosigma akashiwo (Raphidophyceae) and Heterocapsa circularisquama (Dinophyceae) clones isolated from natural environments were respectively grouped into 6 (Tomaru et al. 2004b) and 3 types (Tomaru et al. 2004a) based on their virus sensitivity spectra. Virus sensitivity variation within the host population is considered to be significant for their ecological niche strategies to form and sustain blooms in natural environments. It may be possible that a $C$. debilis population escapes virus-induced total destruction of blooms owing to the clonal variation in viral sensitivity. This is an important focus for future studies to understand the ecological dynamics of $C$. debilis populations.

The cosmopolitan diatom Chaetoceros debilis is one of the most important primary producers in highly productive areas of the world's oceans. It forms blooms not only in shallow coastal environments but also over the wide continental shelf (Ishikawa \& Furuya 2004). In a preliminary field survey we detected viruses infectious to $C$. debilis at $>10^{3}$ infectious units $\mathrm{ml}^{-1}$ in the water of Ariake Sound during host bloom periods (Y. Tomaru unpubl. data). The viruses infectious to $C$. debilis may affect the host population dynamics in various productive areas in the ocean. Future study may show the role of these viruses in wider oceanographic areas.

Acknowledgements. This study was supported by Grants-inAid for Scientific Research (A)(2)(16208019) from the Ministry of Education, Science, and Culture in Japan and by the Min- 
istry of Agriculture, Forestry, and Fisheries of Japan. We thank I. Imai (Kyoto University); M. Yamaguchi, S. Itakura, (FRA, Japan) and T. Nishikawa (Fisheries Technology Institute, Hyogo Prefectural Technology Center for Agriculture, Forestry and Fisheries). We also thank N. Fujii (Fukuoka Fisheries and Marine Technology Research Center) and S. Oda (Fukuoka Prefectural Office) for providing water and sediment samples.

\section{LITERATURE CITED}

Albright LJ, Yang CZ, Johnson S (1993) Sub-lethal concentrations of the harmful diatoms, Chaetoceros concavicornis and $C$. convolutus, increase mortality rates of penned Pacific salmon. Aquaculture 117:215-225

Bettarel Y, Kan J, Wang K, Williamson KE and others (2005) Isolation and preliminary characterisation of a small nuclear inclusion virus infecting the diatom Chaetoceros cf. gracilis. Aquat Microb Ecol 40:103-114

Gubler U, Hoffman BJ (1983) A simple and very efficient method for generating cDNA libraries. Gene 25:263-269

Ishikawa A, Furuya K (2004) The role of diatom resting stages in the onset of the spring bloom in the East China Sea. Mar Biol 145:633-639

Itoh K, Imai I (1987) Rafido so (Raphidophyceae). In: Japan Fisheries Resource Conservation Association (ed) A guide for studies of red tide organisms. Shuwa, Tokyo, p 122-130 (in Japanese)

Lawrence JE, Chan AM, Suttle CA (2002) Viruses causing lysis of the toxic bloom-forming alga Heterosigma akashiwo (Raphidophyceae) are widespread in coastal sediments of British Columbia, Canada. Limnol Oceanogr 47:545-550

Lian C, Zhou Z, Hogetsu T (2001) A simple method for developing microsatellite markers using amplified fragments of inter-simple sequence repeat (ISSR). J Plant Res 114: 381-385

Lopez-Cortes DJ, Bustillos-Guzman JJ, Garate-Lizarraga I (2006) Unusual mortality of krill (Crustacea: Euphausiacea) in Bahia de La Paz, Gulf of California. Pac Sci 60:235-242

Nagasaki K, Tomaru Y, Katanozaka N, Shirai Y, Nishida K, Itakura S, Yamaguchi M (2004) Isolation and characterization of a novel single-stranded RNA virus infecting the bloom-forming diatom Rhizosolenia setigera. Appl Environ Microbiol 70:704-711

Nagasaki K, Tomaru Y, Takao Y, Nishida K, Shirai Y, Suzuki H, Nagumo T (2005) Previously unknown virus infects marine diatom. Appl Environ Microbiol 71:3528-3535

Nakamura Y, Hirata A (2006) Plankton community structure and trophic interactions in a shallow and eutrophic estuarine system, Ariake Sound, Japan. Aquat Microb Ecol

Editorial responsibility: Curtis Suttle, Vancouver, British Columbia, Canada
44:45-57

Nelson DM, Treguer P, Brzezinski MA, Leynaert A, Queguiner B (1995) Production and dissolution of biogenic silica in the ocean: revised global estimates, comparison with regional data and relationship to biogenic sedimentation. Global Biogeochem Cycles 9:359-372

Rines JBE, Hargraves PE (1988) The Chaetoceros Ehrenberg (Bacillariophyceae) flora of Narragansett Bay, Rhode Island, USA. Bibl Phycol 79:196

Shirai Y, Takao Y, Mizumoto H, Tomaru Y, Honda D, Nagasaki K (2006) Genomic and phylogenetic analysis of a single-stranded RNA virus infecting the bloom-forming diatom Rhizosolenia setigera (Stramenopiles: Bacillariophyceae). J Mar Biol Assoc UK 86:475-483

Suttle CA (1993) Enumeration and isolation of viruses. In: Kemp PF, Sherr E, Cole JJ (eds) Handbook of methods in aquatic microbial ecology. Lewis Publishers, Boca Raton, FL, p 121-137

Tarutani K, Nagasaki K, Itakura S, Yamaguchi M (2001) Isolation of a virus infecting the novel shellfish-killing dinoflagellate Heterocapsa circularisquama. Aquat Microb Ecol 23:103-111

Thyrhaug R, Larsen A, Thingstad TF, Bratbak G (2003) Stable coexistence in marine algal host-virus systems. Mar Ecol Prog Ser 254:27-35

Tomaru Y, Katanozaka N, Nishida K, Shirai Y, Tarutani K, Yamaguchi M, Nagasaki K (2004a) Isolation and characterization of two distinct types of HcRNAV, a singlestranded RNA virus infecting the bivalve-killing microalga Heterocapsa circularisquama. Aquat Microb Ecol 34:207-218

Tomaru Y, Tarutani K, Yamaguchi M, Nagasaki K (2004b) Quantitative and qualitative impacts of viral infection on Heterosigma akashiwo (Raphidophyceae) population during a bloom in Hiroshima Bay, Japan. Aquat Microb Ecol 34:227-238

Tomaru Y, Hata N, Masuda T, Tsuji M and others (2007) Ecological dynamics of the bivalve-killing dinoflagellate Heterocapsa circularisquama and its infectious viruses in different locations of western Japan. Environ Microbiol 9:1376-1383

Werner D (1977) Introduction with a note on taxonomy. In: Werner D (ed) The biology of diatoms, Vol 13. Blackwell Scientific Publications, Victoria, p 1-23

$>$ Yamada T, Higashiyama T, Fukuda T (1991) Screening of natural waters for viruses which infect Chlorella cells. Appl Environ Microbiol 57:3433-3437

Yokoyama H, Tamaki A, Koyama K, Ishihi Y, Shimoda K, Harada K (2005) Isotopic evidence for phytoplankton as a major food source for macrobenthos on an intertidal sandflat in Ariake Sound, Japan. Mar Ecol Prog Ser 304:101-116

Submitted: June 5, 2007; Accepted: November 20, 2007 Proofs received from author(s): January 18, 2008 